\title{
Women's Political Participation in Bangladesh in 2008-2018: Status Quo, Obstacles and Future Prospects.
}

\author{
Diana Mutiara Bahari' ${ }^{1}$ Favian Dwi Tantra ${ }^{2}$, Risky Fauzi Widodo ${ }^{3}$ \\ 1,2,3 Universitas Muhammadiyah Yogyakarta, Indonesia \\ Email:dianaaaamb@gmail.com
}

\begin{abstract}
In the contemporary world, the involvement of women in parliament is necessary. However, not all nations uphold the idea of gender equality. Many countries are still trapped by their values and norms such as the patriarchy system. Bangladesh is an example of a country where the patriarchy system has become an obstacle for women to participate in political activities. The current fact has shown its progressivity to involve women in political activities. Therefore, the question arises as of how the future prospect for women in Bangladesh to be able to participate and to involve in the political and parliament activities. This study uses the theory offeminism to examine women's demand that will affect Bangladesh's future policies on women's involvement in political activities. This paper will discuss the current condition and the obstacles faced by the women in Bangladesh regarding political activities. Some obstacles such as women dual role, prohibition of women leadership in Islam, absent of women friendly electoral system as well as present negative women psychology of political culture. The method used in this study is a qualitative based research method. This paper concludes demands appears from the women in Bangladesh to increase their involvement in political activities.
\end{abstract}

Keywords: Bangladesh, Women political participation, Obstacles, Affirmative action 


\section{Introduction}

Many new issues have brought up into international scale in this contemporary world. From the environmental issues, human right issues, transnational crime and gender equality. At the beginning of the emergence of gender equality concern, it was started as the part of human right issues which sees that women have not been given an equal chance in many aspects compared with the men. While gender equality itself means the balance or equal right given to both known gender, masculine and feminine where both gender is highly associated with man and woman. The international actors who concern on this issues have given their thought that there should be an equal chance for man and woman to have the same position in many fields, since it is often men that get higher position or status in the society rather than woman. The unequal or balance position or status between man and woman has triggered some feminine activist who see that woman is as capable as man to handle certain, to show their efforts on promoting the equality on both gender.

In the contemporary world, the development of politics also becomes one of field that women has not been given much equal position as man do, especially in the decision making process. Not all of nations uphold the idea of gender equality that can be seen from the small number of women involved on their political activities. Even for certain countries, the limited number of women involvement in the parliament or political activities is merely a tradition or cultural value that women should not be put into any public space activities and only can have their job at the private life. This particular value known as the patriarchal system. This value has limit women to express their desire and involved themselves in the public society, including in the parliament or politics activity.

An example of a country that still applied this patriarchy system into their daily activities is Bangladesh. Surrounded by strong various culture and norms has sent Bangladesh into one of countries that has less gender equality number among the world. As the developing country, Bangladesh still faced a high number of poverty, which led to the poor condition of education, health and uneven distribution of facilities, especially for women. This make only wealth people that can reach the higher education and better facilities to develop themselves. In the 1979 elections, 
the military regime only have 17 women among 2,125 candidates for 300 seats; none of the women won, and only 3 polled over 15 percent of the vote. According to the 1988 parliamentary election, the provision for reserved seats for women had been allowed to lapse. In the 1981, the Awami League (AL) chose Sheikh Hasina Wazed as their first female head of the party and the Bangladesh Nationalist Party (BNP) chose Begum Khaleda Zia as the first female party chairman. Both are from political families who received sympathy and support of the masses and the media. Khaleda Zia was the wife of former president General Zia (whom assassinated in 1981), proclaimed independence of the country, while Sheikh Hasina is the daughter of father of the nation, Sheikh Mujib (also assassinated in 1975. It is completely seen that the women involvement in Bangladesh's political activities was strongly depends on its family relations or history to the country and none of ordinary women who does not come from a political families have been chosen to have rights in the parliament (Iwanaga, 2008).

\section{Literature Review}

There are many articles discussing about women participations in politics in the area of south Asia including Bangladesh. Article entitled Women's Political Participations in Bangladesh: Rhetoric and Reality by Lasna Kabir mostlikely examine the obstacles faced by Bangladeshi woman participating in politics. Thus Kabir sees that any policies given by the legal government seems just rethoric relate in the fact that the number of women join in any political activities are still in small number. Other article by Pranab Panday entitled Women's Political Participation in Bangladesh and India gives us comparison on how those countries give space for women in joining political activites. The reason why Panday made that comparison is because both countries faced the similar problem which is patriarchy value that still practiced by most of their society. While most of scholar discussing about the obstacles, on our paper we are not just discuss about those factors but we also provide the future prospect for women in Bangladesh by giving analysis where women will have bigger opportunity since there are many supportive actors push the presence of women in Bangladesh.

\section{Theoretical Framework}

Feminism is ideology that 
states equality of rights between man and woman. Feminism is often interpreted as the women's emancipation movement voiced about the improvement of women's status and refused a difference in degree between man and woman. Equality between man and woman in this ideology applies in all aspects. In the early days of its appearance, feminism known as "the struggle of women" but today feminism has developed and known as "the struggle against all forms of injustice".

In history, feminism was born as the beginning of the rise of women to shift status as the second creature after man in this world. Feminism developed in medieval Europe in $16-18^{\text {th }}$ BC. The first feminism is an attempt to deal with patriarchy system. Patriarchy is a system that put men in important position and predominate in roles of political leadership, moral authority, social privilege and control of property. The focus of first feminism is to against the patriarchy system view regarding subordinate position of women who are considered a weaker creature, more emotional and irrational (Suwastini, 2013).

Feminism spearheaded by woman divided into several waves and each wave has a very rapid development. Characterized by the enlightment era happened in Europe where Lady Mary Wortley Montagu and Marquis de Condoracet were the pioneers.

\section{First wave feminism}

The first wave of feminism took place in the late nineteenth and early twentieth century, emerging out of an environment of urban industrialism and liberal, socialist politics. First wave of feminism doesn't refer to the first feminist thinkers in history but it refers to the West's first sustained political equality for women: to open opportunities for women focusing on suffrage.

The first wave officially began at the Seneca Falls Convention in 1848 when almost 200 women for the purpose of equality for women: the social, civil, and religious condition and rights of women. In 1920, Congress passed the $19^{\text {th }}$ Amendment granting women the right to vote (Grady, 2018).

\section{Second wave feminism}

The second wave began in the 1960s which was signed by the publication of The Feminine Mystique by Betty Friedan, followed by establishment National Organization for Women in 1966 
and the interaction of conscious raising (CR) groups in the end of 1960s.

The second wave of feminism themed "Women's Liberation" is considered as a revolutionary collective movement. This wave appear as a reaction to women's dissatisfaction with the various discriminations they experienced even though legal and political emancipation had been achieved by the first wave of feminism. Therefore, the second wave of feminism focuses more on issues that directly affect women's lives such as reproduction, childcare, sexual violence, female sexuality, and the problem of domesticity (Rampton, 2015).

\section{Third wave feminism}

The third wave of feminism began in the early 1980 s to the early 1990s, was marked by an understanding of the increasingly diverse feminism movement. Wherein the political movement has prioritized women's politics, ethnicity, and subject positions that are often discussed in the "postmodern politics" rubric. Wherein something that has been marginalized and marginalized in the "postmodern theory", specification of their position begin to be highlighted with their differences of opinion from other groups and individuals (Grady, 2018).

So, even though each wave has a different focus, feminists provide support, encouragement, and inspiration about the importance of women's roles and positions, special roles and positions in the realm of culture and politics.

Based on this explanation, we use the concept of feminism especially the first wave of feminism. The focus of feminism in the first wave is to fight for women's suffrage or emancipation in the political sphere. Through the concept, we can find out obstacles in parliament and woman in parliament in future prospect.

\section{Methodology}

This research uses qualitative descriptive research methods with a secondary data analysis approach. The qualitative approach in this research is to match empirical reality with the prevailing theory by using descriptive methods. Whereas qualitative secondary data is a method by using secondary data as the main source. Secondary data may include field notes, personal documents, and other official documents. 


\section{Result and Disscussion}

Bangladesh Progress for Woman to Participate in Jatiya Sangshad (National Parliament)

As developing country, Bangladesh is quiet progressive in terms of woman's political participation despite it is not significantly shown in the number. Since getting independence in 1972, Bangladesh has recognized and legalized their constitution to guarantee woman presence in any political activities. On the article 28(1) stated that "the state shall not discriminate against any citizen on grounds only of religion, race, caste, sex or place of birth", it means that the Bangladesh constitution has no limitation and recognizes woman in the aspect of politics. Again, in article 28(2) stated that "women shall have equal rights with men in all spheres of the state and public life".

Table 1. Elected women in joining parliament 1973-2001

\begin{tabular}{|c|c|c|c|c|l|}
\hline Year & $\begin{array}{c}\text { \% of Women } \\
\text { Candidates }\end{array}$ & $\begin{array}{c}\text { Won in direct } \\
\text { seats or by- } \\
\text { elections }\end{array}$ & $\begin{array}{c}\text { Total } \\
\text { elected } \\
\text { women }\end{array}$ & $\begin{array}{c}\text { Reserved } \\
\text { seats }\end{array}$ & $\begin{array}{l}\text { \% off women in } \\
\text { the parliament }\end{array}$ \\
\hline 1973 & 0.3 & 0 & 0 & 15 & $\begin{array}{l}4.8 \% \text { out of } 315 \\
\text { seats }\end{array}$ \\
\hline 1979 & 0.9 & $0+2$ & 2 & 30 & $\begin{array}{l}9.69 \% \text { out of } \\
330 \text { seats }\end{array}$ \\
\hline 1986 & 1.3 & $5+2$ & 7 & 30 & $\begin{array}{l}11.21 \% \text { out of } \\
330 \text { seats }\end{array}$ \\
\hline 1988 & 0.7 & 4 & 4 & 0 & $\begin{array}{l}1.33 \% \text { out of } \\
300 \text { seats }\end{array}$ \\
\hline 1991 & 1.5 & $8+1$ & 9 & 30 & $\begin{array}{l}11.81 \% \text { out of } \\
330 \text { seats }\end{array}$ \\
\hline 1996 & 1.4 & $13+2$ & 15 & 30 & $\begin{array}{l}13 \% \text { out of } \\
330 \text { seats }\end{array}$ \\
\hline 2001 & 1.8 & 6 & 6 & 0 & $\begin{array}{l}2 \% \text { out of } 300 \\
\text { seats }\end{array}$ \\
\hline
\end{tabular}

Source: Election Commission of Bangladesh 
Both articles shown that Bangladesh actually aware towards woman participation in any political activities throughout the country.

In order to involve more women in parliament, Bangladesh government also establishes several legislations such as Women and Children Repression Act 1995 that amended in 2000 and Dowry Prohibition Act 1980 that amended in 1982, these legislations are an attempt to ensure women presence in political activities in Bangladesh (Ahmed, 2008). However, since its independence, in terms of number, women political participation in Bangladesh has not showing the significant number in the past decades due to Bangladeshi women are disadvantaged and denied equal rights with men. In the period of 1973 election to 2001, there are no more than $12 \%$ of women joined in parliament. However in 2014 the election result show the percentage of women conquer the parliament seats increase up to $20.3 \%$ or 71 seats out of 350 seats (Kumar, 2017). The affirmative action given by the Bangladesh government atleast can attract women participation to compete for legislative seats

Despite its number, Bangladesh government did not remain silent in order to push the involvement of women in joining political activities. Since the 1979 CEDAW introduced gender based quotas, many countries start to adopt this form of affirmative action (Baldez, 2006). Affirmative action itself is a form of policy to give particular entities such as gender based, race, religions and faith and so on who are underrepresented in various position such as parliament in order to create and to accommodate a good policy for their entities interest. However, before the enactment of 1997 Act, the participation of women in parliament was meager. Before amended in 1997, seats for woman in parliament was reserved and filled by nomination or indirect election because in political contest women will find difficulties against men (Panday \& Li, 2014). The 1997 Act was a starting point for the development of women participation in politics, in this time the affirmative action to allow women to compete for parliament seats through direct election by suffrage to the three women-only reserved seat, in which they can only compete with another woman candidates and men are not allowed to compete against women. This policy is the first time for women in Bangladesh to compete through direct election with women 
candidates only to provide elected candidates equal legitimacy, power and rights as what men earned (Sultana, 2000).

Despite the separation policy for women through direct election, there is also other policy which is territorial demarcation to appoint a ward for woman members, the nine wards for general member were grouped into three larger wards for the purpose of election for women in parliament seats (Panday \& Li, 2014). Even though in the national level, women still find difficulties to have a seats, after 1997 Act established women in local level dramatically increase as around 12.828 women were elected in 1997 local level election (Zaman, 2016). On May 2004, Bangladesh Parliament called Jatiya Sangshad have passed the $14^{\text {th }}$ constitutional amandement to add extra 15 reserved seats for women in parliament to 345 which $45(15 \%)$ seats are reserved for women only. In the 2018 election, Bangladesh government add extra 5 seats for reserved seats for women, so in total is 350 seats where 50 seats are reserved. This table below show the increasing women seats in parliament after establishment of $14^{\text {th }}$ constitutional amandement (Kumar, 2017).

Table 2. Parliament Election result 2008-2018

\begin{tabular}{|c|c|c|c|c|}
\hline Year & $\begin{array}{c}\text { Women in } \\
\text { Reserved Seats }\end{array}$ & $\begin{array}{c}\text { Women in } \\
\text { General Seats }\end{array}$ & $\begin{array}{c}\text { Total Number of } \\
\text { Women in Parliament }\end{array}$ & Percentage \\
\hline 2008 & 45 & 6 & 51 & 14.7 \\
\hline 2014 & 45 & 19 & 64 & 18.6 \\
\hline 2018 & 50 & 22 & 77 & 22 \\
\hline
\end{tabular}

Source : Election Commission of Bangladesh

The Bangladesh government make a progressive attempt to always involve women in any political activities including for national parliament. Even though the result is not that significant, but the fact prove that in every election period shown the rise of women elected in national parliament.
The affirmative action given by Bangladesh government can boost the involvement of women.

\section{Obstacles that Hamper Women Participation in National Parlia- ment}

Bangladesh is a country located in South Asia identic with its 
patriarchy system where society tend to look man upper than woman. Patriarchy itself is a social system in which males have greater accesses in occupying political roles, moral authority and control of property. Even though the participation rate of women in political activities in Bangladesh is always progressive, but then their presence in political agenda and decision making process are still seen as a symbolic role since the affirmative action always overshadowing their presence. However survey conducted by the Asian Development Bank (ADB) back in 2004 show that more than $70 \%$ women joined in political activities both in national or local level were not aware of their rights and responsibilities as woman represntatives in parliament (Mukhopadhyay, 2005). The big argument talking about the obstacle for women to participate in politics is that the idea of patriarchy value that still adopted by most of Bangladeshi. Moreover in the other part of the world, feminist movement have no longer need the acknowledgement about their presence in any activities including politics. There are several factors that support the existence of patriarchy value that hamper the presence of women in Bangladesh to join in politics even though the world have progressive anyway with globalization.

First factor is lack of control over corruption and their own incomes. It is not surprised when the election period come in Bangladesh there will be "black money" easily thrown in rural area such as district. Black money refers to money that is illegal and unaccounted consider as result of corruption that used by the political candidates to win the election by bribing or "buying votes" especially from people stayed in slum area. The political candidates which dominated by men are depended towards this black money since it needs bigger money to win election and women have no control towards this. The fact show that many businessmen are involved in national parliament since the very first election held in Bangladesh and its number always increase in every election continuously. In the ninth parliament there are around $59 \%$ of the elected members of parliament are businessmen and they are the person who will be nominated by their party leaders by paying huge amount of money and the result is many businessman were elected to become corrupt member of parliament through such of nominations process (Chowdhury, 2009). 
In the other hand talking about private income, it is still hard for women to independently spend their own income for themselves. Most of women spend their money jointly with their husbands, therefore they could not manage their money for political purpose. Due to the patriarchy value, husband tend to look women as their property thus women income automatically belong to their husband since their wives also their own property. Men always take control towards their wives income so that women have no autonomy towards their personal income used for political activities.

Second factor is related to the economic incapability that lead to the less access to the education. Education is primary source to obtain knowledge used for woman to have equal political position with man and it can influence woman political outlook. However woman in Bangladesh are still lack of access towards education considering number of illiteracy is quiet high especially in slum area. It reflect on the member of parliaments itself when the member of parliament in 1996-2001 consist by 37 woman, only around $37 \%$ of them had degree from university level. In contrast, most of man in parliaments seats were hold bachelor degree, it made the presence of woman in parliament be more overshadow when it came to the decision making process. The exact thing also happened in local level (Union Parishad), woman who sat for legislative in local level were dominated by housewife where they are actually not aware about political process. Therefore many of them assigned assistant from men to help them run the local legislative, and it is create stigma in society that woman actually incapable to do job as society representative in legislative. For the society live in slum area, the presence of women in politics did not contribute that much towards their life. They not even aware towards their political rights and responsibility so they can easily bribed by the candidates using black money and taking for granted giving their votes to them (Chowdhury, 2009).

Those two basic factors lead to the preservation of patriarchy value in Bangladesh that hamper the political development for woman. Lack of control and limit education makes woman difficult to break their boundaries in order to join political activities. Beside that, most of society live in slum area are not supportive towards woman in politics since they are not aware about their political rights since 
they lack of access toward proper information about politics. This condition getting worse when their representatives in parliament doing corruption and use that money to ensure their position in parliament. This going to create an evil circle where parliament are dominated by "powerful men" and the other especially women remain in their position

\section{Future Prospects}

The success of the struggle for feminism and the demands of democracy so that all citizens actively participate in politics, for better governance requires the participation of women in all fields including politics, in other words women are expected to take part in decision making procedure.

Sue Thomas offered five reason why woman needs to increase their participation in politics. First, the equal opportunities for both sexes to hold political office can increase the legitimacy of democratic governments that claim to represent all of their citizens. Second, citizens believe that all citizens have equal opportunities to participate in decision making procedure. If it can be realized, so it can be increase the level of trust and support government and this can help create a more stable government. Third, women are large talent group. Their abilities, points of view and ideas can give benefit society by involving male and female office holders at once. Fourth, a government that embraces male and female leaders convey message to the young men and women, as well as adults from age groups, that the political world is open to all people and all groups, not only as an exclusive men. Fifth, the importance reason of including women in ranks of political leaders is based on the fact that men and women have different experiences. With this difference, men and women can complement and enhance their respective roles (Idris, 2010).

The participation of woman is also important for reasons of fairness, legitimacy, stability and political symbolism. Political activists and politicians who struggle to increase the number of female office holders argue that women will make a difference in politics, women will represent the perspectives, needs and interests of female citizens. Some observers have concluded that the presence of woman is needed in politics to ensure the voices, interests and priorities of woman are so underrepresented in 
government and in laws enacted by the government.

Furthermore, the United Nation declared "International Women's Day". It is a day when woman is recognized for her achievements without regard to divisions, whether national, ethnic, linguistic, cultural, economic or political. It also increases the attention of citizens, politicians and academics about the role of woman in politics, especially her role as holder of political office. So, this charter was the first international agreement to affirm the principle of equality between women and men (International Women's Day, n.d.).

At this time, Bangladesh, the community has begun to agree and hope for greater women's participation, although for women there are still many obstacles that must be overcome. In addition, it is not easy for women to enter the political world, even though there are no formal rules that block but it is also a difficult choice. When a woman has chosen to pursue a career in politics, woman must be fully prepared to bear all the risks of professionalism. They must be prepared to sacrifice time, feelings, opportunities that should be given to their families.

\section{Supporting actor of women in po-} litics

Woman's own organizations which are fighting to ensure equal social and political rights for women, have been important factors that led both the governments of Bangladesh to bring about changes in policies regarding woman's participation in politics. The experience in Bangladesh shows that woman's activism picked up them the space that they presently have and which they likewise need to shield and secure (Panday P. K.).

For more than five decades, feminist organizations in Bangladesh have been trying to increase the resources of the various bases and have focused on the mobilization against gender inequality in the country. Organization that were initially only concerned about women's issues began to promote and demand that the government focus more on the fate of national women. A few examples of the hundreds of organizations that are dedicated to the advancement of women Bangladesh such as 'Jatiya Mahila Sanshad', 'Women for Women','Naripokho', 'Bangladesh National Women's Lawyer Association (BNWLA), 'Bangladesh Nari Progati Sangha', Democracy Watch', and 'Khan Foundation' are 
strong advocates of women's rights, gender equality, and women's empowerment (Ahmed, 2008). Furthermore, these organization also acts as a social actor that connects between woman and the government of Bangladesh and seeks to contribute towards gender issues. Organizations that appear to act as a forum for leadership training for woman and as a conduit to bring woman's voices into proper perspective in the future. It can be said that there is an opportunity for woman to join parliamentary positions by the many actors who support them.

\section{Conclusion}

Although the number of womens participation in the Bangladesh's Parliament and political activities shows an increasing number, yet the obstacles remain exist and faced a challenges or difficulties to completely free out of the obstacles. As it still restricted by norms and values in the surrounding environment and societies, such as patriarchy system and Islamic values which says women should stay at the private life since Bangladesh is one of largest number of Muslim followers.

Participating Women in Parliament in 2008 - 2018

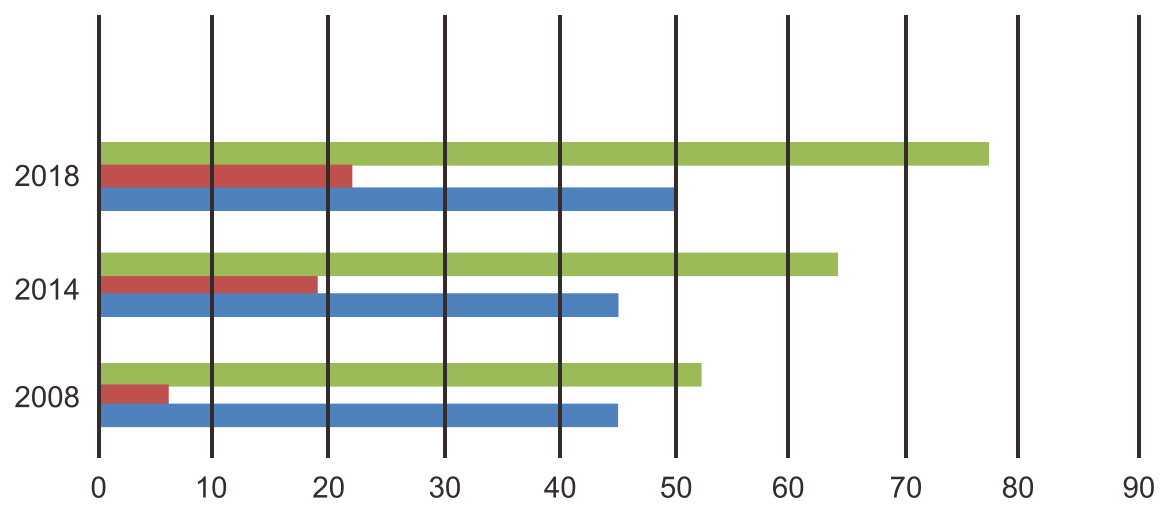

Total Number of Women in Parliament $\square$ Women in General Seats $\square$ Women in Reserved Seats

As it seen at the graphic table above, we can conclude that there is increasing number of women participation in the Bangladesh's political activities, especially in the Parliament with almost 80 women.
While in the General Seats, the number of women involved has significantly increased since 2008 to 2018 and in the Reserved Seats, it remains stable or does not increased much. 
But the development of technology and information has spread the values of gender equality to reach the Bangladesh's society and encourage the emergence of supporting actors to make woman able to involved in any kind public activities, including in the political field. As the supporting actors in which formed as woman organization such as Women for Women, Bangladesh's National Women for Law Association are growing significantly to support the women's right and gender equality, the future prospect for women to be more involved in the parliament activities will likely increased and create a fairness between men and women's right at any public activities.

\section{References}

Ahmed, K. U. (2008). Women in Poli tics Bangladesh. Women's Political Participation and Representation in Asia, Obstacle and Challanges, 279-280.

Baldez, L. (2006). The Pros and Cons of Gender Quota Laws: What Happens When You Kick Men Out and Let Women In? Poli tics and Gender, 2(1), 102-109.

Chowdhury, F. D. (2009). Problems of Women Participations in Bang ladesh Politics. The Round Ta- ble: The CommonwealthJournal of International Affairs, 98(404), 559-560.

Grady, C. (2018, July 20). The wa ves of feminism, and why people keep fighting over them, explained. Retrieved from VOX: https://www.vox.com/ 2018/3/20/16955588/feminism-waves-explained-firstsecond-third-fourth

Idris, N. (2010). Phenomenon, Femi nism and Political Self Selection for Women. WACANA, 117.

International Women's Day . (n.d.). Retrieved from United Nation: http://www.un.org/en/events/ womensday/history.shtml

Iwanaga, K. (2008). Women's Political Participation and Representation in Asia: Obstacles and Challenges. Malaysia: NIAS Press.

Kumar, P. (2017). Participation of Women in Politics: Worldwide experience. IOSR Journal Of Humanities And Social Science, 22(12), 82-83.

Mukhopadhyay, M. (2005). Decentralization and Gender Equity in South Asia: An Issue Paper. Canada: The International Development of Research Centre.

Panday, P. K. (n.d.). Women's Political Participation In Bangladesh 
and India: Symbolic or Real Empowerment? 31.

Panday, P., \& Li, L. C. (2014). Women's Political Participation in Bangladesh: Role of Women's Organizations. International Journal of Public Administration, 37(11), 730-731.

Rampton, M. (2015, October 25). Four Waves of Feminism. Retrieved from Pacific University Oregon: https://www.pacificu. edu/about/media/four-wavesfeminism

Sultana, A. (2000). The role of train ing in the empowerment of wo men in Union Parishad: An ana lysis. Lok Proshashon Samoyke, 14-15.
Suwastini, N. K. (2013). Perkembangan Feminisme Barat Dari Abad Kedelapan Belas Hingga Postfeminisme: Sebuah Tinjauan Teoritis. Jurnal Ilmu Sosial dan Humaniora, 199.

Zaman, F. (2016). Bangladeshi Wo men's Political Empowerment in Urban Local Governance. South Asia Research, 32(2), 8586. 